\title{
Development of Galactose Biosensor Based on Functionalized ZnO Nanorods with Galactose Oxidase
}

\author{
K. Khun, Z. H. Ibupoto, O. Nur, and M. Willander \\ Division of Physical Electronic and Nanotechnology, Department of Science and Technology, Linköping University, \\ Campus Norrköping, 60174 Norrköping, Sweden
}

Correspondence should be addressed to K. Khun, kimleang.khun@liu.se

Received 31 December 2011; Revised 28 April 2012; Accepted 13 May 2012

Academic Editor: P. Siciliano

Copyright $(9) 2012 \mathrm{~K}$. Khun et al. This is an open access article distributed under the Creative Commons Attribution License, which permits unrestricted use, distribution, and reproduction in any medium, provided the original work is properly cited.

\begin{abstract}
The fabrication of galactose biosensor based on functionalised $\mathrm{ZnO}$ nanorods is described. The galactose biosensor was developed by immobilizing galactose oxidase on $\mathrm{ZnO}$ nanorods in conjunction with glutaraldehyde as a cross-linker molecule. The IRAS study provided evidence for the interaction of galactose oxidase with the surface of $\mathrm{ZnO}$ nanorods. The electromotive force (EMF) response of the galactose biosensor was measured by potentiometric method. We observed that the proposed biosensor has a linear detection range over a concentration range from $10 \mathrm{mM}$ to $200 \mathrm{mM}$ with good sensitivity of $89.10 \pm 1.23 \mathrm{mV} / \mathrm{dec}$ de. In addition, the proposed biosensor has shown fast time response of less than $10 \mathrm{~s}$ and a good selectivity towards galactose in the presence of common interferents such as ascorbic acid, uric acid, glucose, and magnesium ions. The galactose biosensor based on galactose oxidase immobilized $\mathrm{ZnO}$ nanorods has a shelf life more than four weeks.
\end{abstract}

\section{Introduction}

Recently, zinc oxide $(\mathrm{ZnO})$ has become one of the most important semiconductor materials used in the research due to its attractive properties such as a large band gap of $3.37 \mathrm{eV}$, high exciton binding energy of $60 \mathrm{meV}$, and optical gains $300 \mathrm{~cm}^{-1}$ at room temperature [1-4]. $\mathrm{ZnO}$ nanomaterials exist in variety of one-dimensional (1D) nanostructures such as nanorods, nanotube, nanowalls, and nanowires, and all these nanostructures have potential applications in making devices such as light emitting diodes (LEDs), optical waveguides, nanolaser [5-9], gas sensor [10], chemical sensor [11], and biosensor [12]. Due to the high surface area to volume ratios, nontoxicity, chemical stability, and enhanced electrochemical response, these nanostructures possess a potential for sensor application [10-13]. Among the many nanostructures of $\mathrm{ZnO}$, nanorods were largely used for sensing purposes because of their high surface area to volume ratios [14-19]. $\mathrm{ZnO}$ nanorods are $n$-type semiconductor material and their electrical characteristics are well defined through the adsorption/desorption properties of chemical substance [20-25].

Galactose in the human body is metabolized after the lactose hydrolysis by different enzymes such as galactokinase, galactose-1-phosphate uridyl transferase, and beta galactoside and galactose-6-phosphate epimerase. The galactosemia is an inherited disorder analyzed from the inability of human body to utilize galactose because of the insignificant amount of one or more of these enzymes, which metabolize galactose and result in galactosemia in the human body. It is the higher level of galactose in the urine and blood which is responsible for the symptoms of galactosemia, galactosuria, and other metabolic disorders [26]. The classic galactosemia is a familiar type of galactosemia which is due to the absence of galactose-1-phosphate uridyl transferase (GALT) or its lower quantity. The GALT enzyme in the human body changes the galactose into the glucose that provides energy. The intensity of galactosemia is different for a person who is suffering from it, because every person has a different level of these enzymes; hence the needed therapy varies from one 
person to another. Persons with galactosemia should keep away from milk and dairy products, because those dietary foods have high level of galactose. The level of galactose-1phosphate in the blood should be kept below 3-4 mg dl-1 Fruits, vegetables, grains, breads, fats, and sugars do not have components containing galactose. Some vegetables and fruits have a few amount of bound galactose which is not consumed by the human body; therefore it can raise the galactose-1-phosphate level in the blood.

Non processing galactosemia raises galactose and galactose-1-phosphate in the blood stream and body tissues. Generally, the human body can have problems with feeding and growth because of the unrecognized galactosemia. Due to the unrecovered galactose, babies may suffer from some diseases such as cataracts, liver diseases and kidney problems [27-30]. However, increased level of galactose and galactose1-phosphate can be dangerous to brain and finally leads to death. Because of the galactosemia, children may become disable in learning and girls may suffer from ovaries problems [31,32]. The human body can be fed with soy formula, nutramigen or galactose-free formula such as zerolac, nusobee, and simyl-MCT and also different ways $[33,34]$. Galactose in the food can be determined by different types of biosensors such as biostrips [35-39]. The quantity of galactose in the dairy samples is measured by biostrip method and the results of this method were compared with reported values of different dairy samples [40].

There are many methods used for the firm binding of enzyme molecules with the biosensor electrodes and a very common method is the use of cross-linker molecule for the entrapment of enzyme molecules. Many synthetic polymers such as polyacrylamide, polyurethane, polyvinyl alcohol, polyvinylchloride, polyhydroxyethyl methacrylate, and polyvinyl formal (PVF) were frequently used to detect the galactose; due to their several advantages such as higher mechanical strength, chemical resistance and can also act as a complex buffer candidates. It has also been reported the amperometric galactose biosensor based on the galactose oxidase immobilized Langmuir-Blodgett (LB) film [41, 42].

In this work, a simple, sensitive and highly selective potentiometric galactose biosensor is developed by immobilizing galactose oxidase on $\mathrm{ZnO}$ nanorods grown on gold coated glass.

\section{Experimental Detail}

2.1. Material. Galactose oxidase (150UN), D-galactose, glutaraldehyde (GA) (crosslinking molecule), zinc nitrate hexahydrate $\left[\mathrm{Zn}\left(\mathrm{NO}_{3}\right)_{2} \cdot 6 \mathrm{H}_{2} \mathrm{O}\right]$, hexamethylenetetramine (HMT), D-glucose, and L-glucose-fructose were purchased from Sigma Aldrich Sweden. A phosphate buffer solution (PBS) with $10 \mathrm{mM}$ concentration was prepared using $2.7 \mathrm{mM}$ potassium chloride $(\mathrm{KCl}), 0.135 \mathrm{mM}$ sodium chloride $(\mathrm{NaCl}), 1.5 \mathrm{mM}$ potassium dihydrogen phosphate $\left(\mathrm{KH}_{2} \mathrm{PO}_{4}\right)$, and $8 \mathrm{mM}$ sodium dihydrogen phosphate $\left(\mathrm{NaH}_{2} \mathrm{PO}_{4}\right)$ in deionized water. The $\mathrm{pH}$ of the buffer solution was adjusted by adding $100 \mathrm{mM}$ hydrochloric acid $(\mathrm{HCl})$ and $100 \mathrm{mM}$ sodium hydroxide $(\mathrm{NaOH})$. All these chemicals were also purchased from Sigma Aldrich Sweden. The chemicals used other than these were of analytical grade.

\subsection{The Fabrication of Gold Coated Glass Substrate and} Growth of $\mathrm{ZnO}$ Nanorods. The process of fabrication of gold coated glass substrates was as followed: firstly the glass substrates were washed with isopropanol in ultrasonic bath for 10 minutes, and then cleaned with deionized water and dried with nitrogen gas. After that the clean glass substrates were placed in the vacuum chamber of (Satis CR 725), for producing a $10 \mathrm{~nm}$ layer of titanium as an adhesive surface, and then followed by evaporation of a $100 \mathrm{~nm}$ thickness layer of gold. $\mathrm{ZnO}$ nanorods were grown on these substrates by the hydrothermal method, which is a low cost, a simple, and a low temperature growth method [19]. After the duration of growth, the nanostructures were characterised by the field emission scanning electron microscopy (FESEM) and it was seen that $\mathrm{ZnO}$ nanorods were highly dense and well aligned as shown in Figure 1(a).

\subsection{Immobilization of $\mathrm{ZnO}$ Nanorods with Galactose Oxidase.} We have immobilized five independent biosensor electrodes based on $\mathrm{ZnO}$ nanorods and immobilized with galactose oxidase in combination with GA as a cross-linking molecule for the galactose oxidase enzyme as shown in Figure 1(b). We prepared $2.5 \%$ GA solution in $0.1 \mathrm{mM}$ PBS and also a galactose oxidase solution was prepared in PBS having a concentration of $150 \mathrm{UN}$ per $4 \mathrm{ml}$ of PBS. We functionalised the $\mathrm{ZnO}$ nanorods electrodes within a mixture of galactose oxidase and GA for 4 minutes. We also investigated the effect of immobilization time on the response of the sensor electrode, but at 4 minutes the response of the sensor electrode was found higher due to almost complete physically adsorbed layer of galactose oxidase on the surface of $\mathrm{ZnO}$ nanorods.

\subsection{IRAS Study of Galactose Oxidase Immobilized $\mathrm{ZnO}$} Nanorods. Figure 2(a) shows the FTIR spectra of $\mathrm{ZnO}$ nanorods. This study revealed that the peak at $549 \mathrm{~cm}^{-1}$ the stretching modes correlated with $\mathrm{ZnO}$ nanorods [43]. The peaks at $3668 \mathrm{~cm}^{-1}$ might be for the $\mathrm{O}-\mathrm{H}$ hydroxyl stretching vibration of absorbed water molecules on the surface of the $\mathrm{ZnO}$ nanorods. The peak at $2380 \mathrm{~cm}^{-1}$ was found to be for the $\mathrm{CO}_{2}$ during the measurement. When the galactose oxidase was immobilized on $\mathrm{ZnO}$ nanorods, then the peaks $549,699,1163,2533$, and $3668 \mathrm{~cm}^{-1}$ were shifted to 554 , $652,912,2259$, and $3247 \mathrm{~cm}^{-1}$, respectively, as shown in Figure 2(b). This clearly shows the interaction between the galactose oxidase enzyme molecules with the surface of the $\mathrm{ZnO}$ nanorods. The appearance of extra peaks in the spectra might be due to possible impurity in the sample.

The electromotive force (EMF) response of the proposed biosensor based on the immobilized $\mathrm{ZnO}$ nanorods was measured by potentiometric method, which used the immobilized $\mathrm{ZnO}$ nanorods as a working electrode and silver-silver $\mathrm{Ag} / \mathrm{AgCl}$ as reference electrode. For avoiding the reduction in the activity of the immobilized galactose oxidase, the biosensor electrodes were kept at $4^{\circ} \mathrm{C}$ when not in use. 


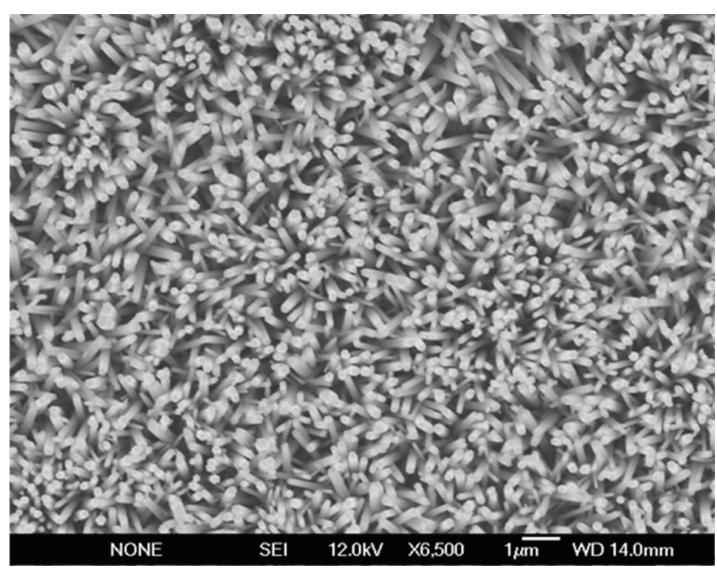

(a)

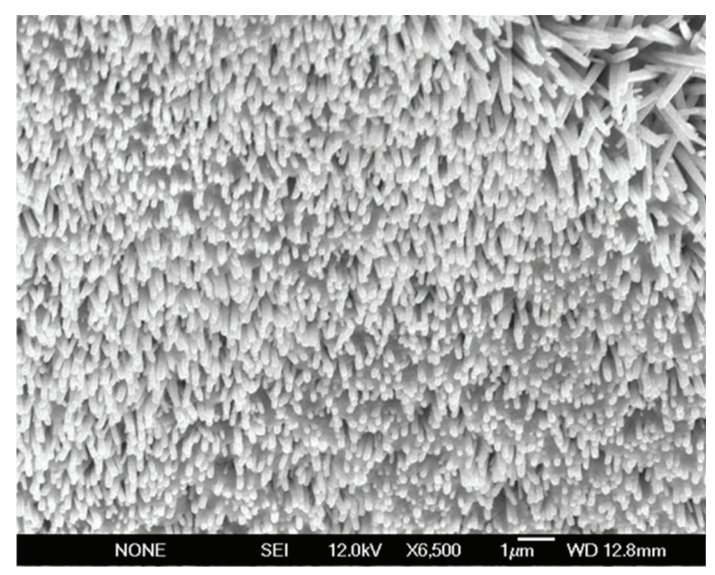

(b)

Figure 1: A typical SEM image of $\mathrm{ZnO}$ nanorods grown on gold coated glass substrate using the low temperature growth method: (a) showing the $\mathrm{ZnO}$-nanorods as grown and (b) with immobilized galactose oxidase enzyme.

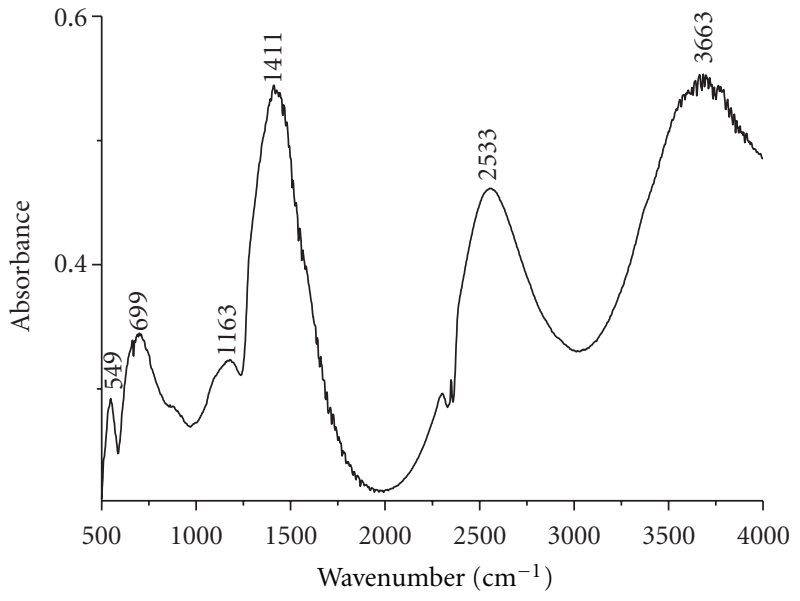

(a)

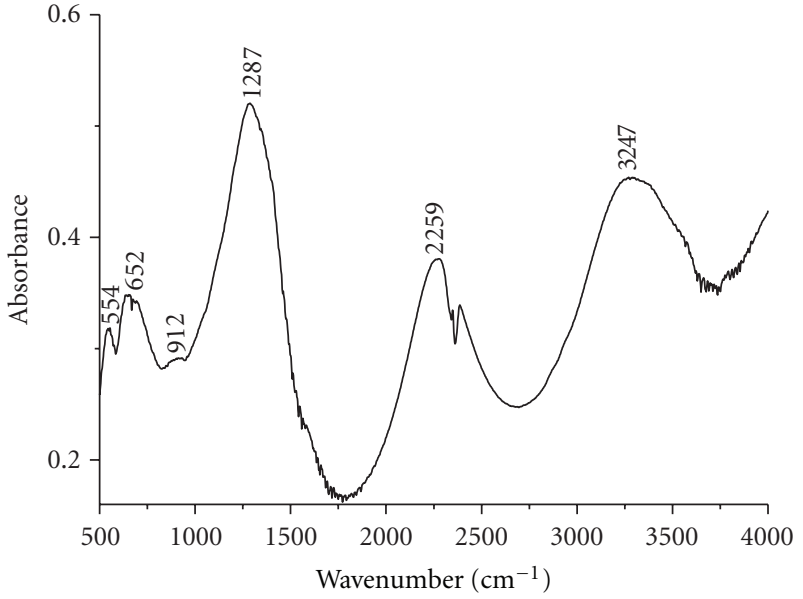

(b)

FIgure 2: The FTIR spectrum (a) the pure $\mathrm{ZnO}$ nanorods and (b) galactose oxidase immobilized on $\mathrm{ZnO}$ nanorods.

\section{Results and Discussions}

3.1. The Characterisation of EMF Response of Functionalized $\mathrm{ZnO}$ Nanorods Selective Electrode. The EMF response of the potentiometric galactose biosensor based on galactose oxidase immobilized $\mathrm{ZnO}$ nanorods is shown in Figure 3. During the experiment we observed that the EMF response is the function of the galactose concentration and also on the rate of oxidation of galactose in the presence of galactose oxidase on the surface of $\mathrm{ZnO}$ nanorods. Which increases the concentration of unstable galactohexodialdose; $\mathrm{H}_{2} \mathrm{O}_{2}$ and further it decompose into the gluconic acid in the testing solution of galactose. It is the gluconic acid which increases the amount of $\mathrm{H}_{3} \mathrm{O}^{+}$ions into analyte solution. So in result the EMF response of the sensor electrode was increasing with the increase of the concentration of the electrolytic solution. It also has been reported that when there are the number of charges around the working electrode, then potential is observed [44]. The EMF response of enzyme based

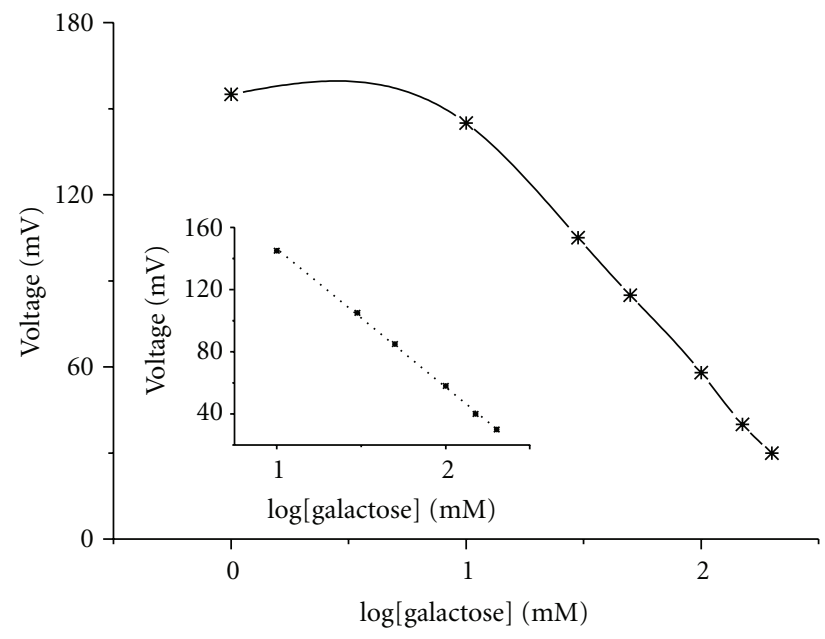

FIGURE 3: The calibration curve for galactose sensor based on galactose oxidase immobilized $\mathrm{ZnO}$ nanorods. 


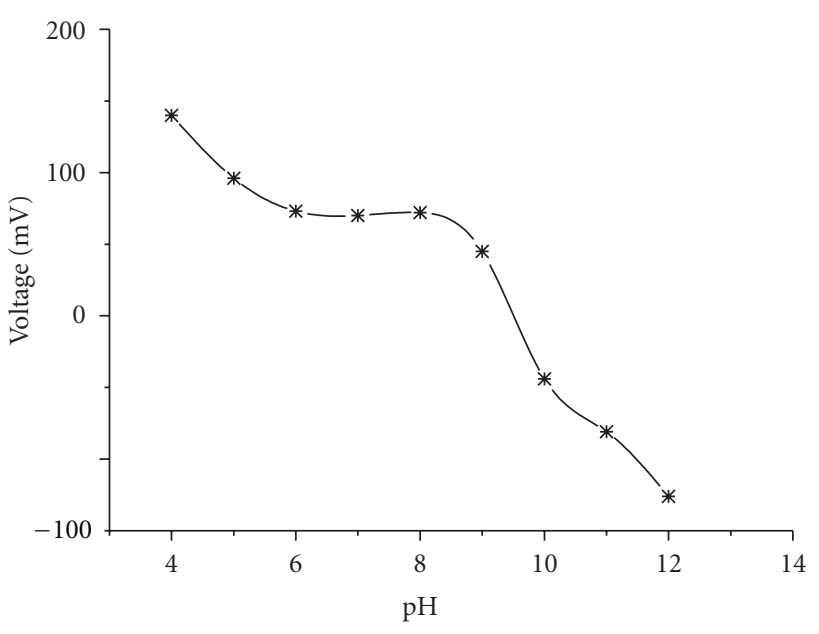

FIgure 4: The EMF response versus different $\mathrm{pH}$ values.

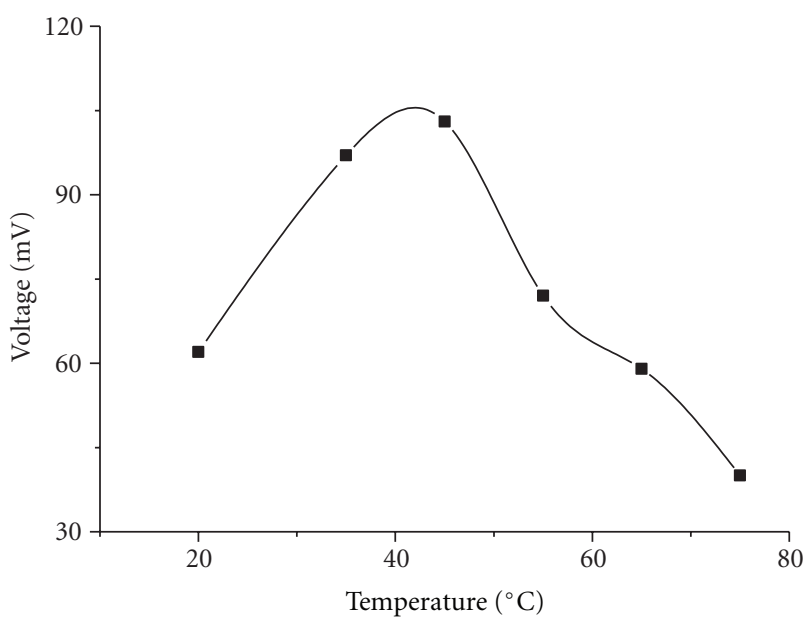

Figure 5: The EMF response versus different temperatures.

biosensors also depends on the catalytic efficiency of enzyme in specific conditions, higher is the catalytic efficiency of enzyme, greater is the EMF response of biosensor electrode. We tested the working biosensor electrode into different galactose concentrations from $1 \mathrm{mM}$ to $200 \mathrm{mM}$; it had shown the linearity from $10 \mathrm{mM}$ to $200 \mathrm{mM}$. The biosensor detected $1 \mathrm{mM}$ concentration of galactose, but it was out of the linear range, and biosensor followed the Nernst's equation as shown in Figure 3. The sensitivity and detection limit of the biosensor electrode was found to be about $89.10 \pm 1.23 \mathrm{mV} /$ decade and $1 \mathrm{mM}$, respectively.

3.2. Effect of $p H$ and Temperature on the Operation of Biosensor. The purpose of this study was to demonstrate the effect of $\mathrm{pH}$ and temperature on the EMF of the present galactose sensor electrode. It has been investigated that the $\mathrm{pH}$ and temperature has pronounced effect on the performance of the biosensors. The effect of $\mathrm{pH}$ was studied for the $\mathrm{pH}$ range of 4 to 12 . We observed that the biosensor showed the same response for a $\mathrm{pH} 6$ and 7, but above $\mathrm{pH} 7$

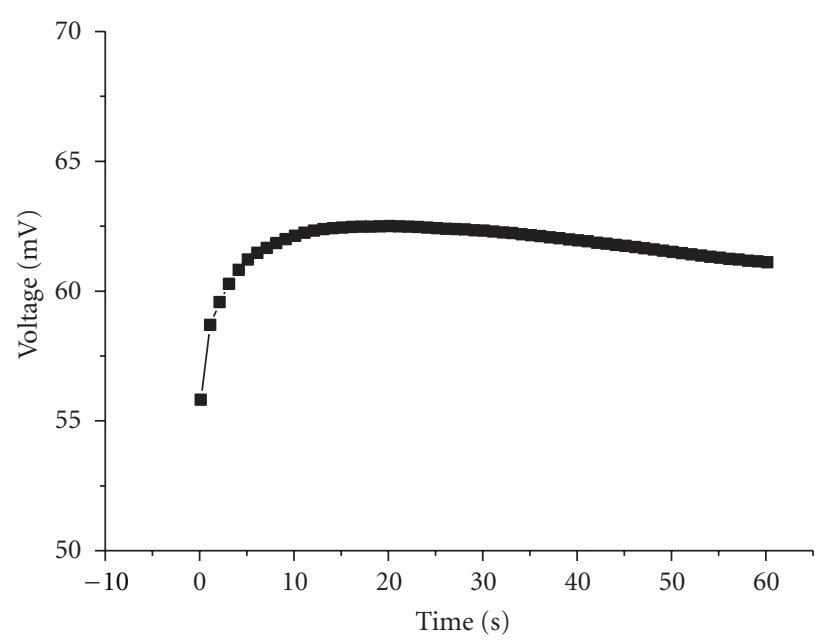

FIGURE 6: The response time of galactose biosensor into the $100 \mathrm{mM}$ solution.

TABLe 1: The calculated selectivity coefficient values for different interferents in $10 \mathrm{mM}$ and $30 \mathrm{mM}$.

\begin{tabular}{lcc}
\hline Interference & \multicolumn{2}{c}{$\log K$} \\
\hline Concentration & $10 \mathrm{mM}$ & $30 \mathrm{mM}$ \\
$\mathrm{Mg}^{2+}$ & -2.00 & -1.63 \\
Glucose & -1.80 & -1.32 \\
Vitamin C & -3.34 & -2.15 \\
Uric acid & -2.32 & -1.58 \\
\hline
\end{tabular}

the EMF response was decreasing due to the fact that the galactose oxidase has optimum $\mathrm{pH}$ around 7 and higher $\mathrm{pH}$ might be decreasing the activity of immobilized enzyme on the $\mathrm{ZnO}$ nanorods [45]. However, the biosensor has shown increasing response for $\mathrm{pH}$ values below 5 , because of the higher concentration of the hydronium ions, but we carried out all experiments at $\mathrm{pH} 7$ in order to avoid the dissolution of $\mathrm{ZnO}$ nanorods in acidic medium as shown in Figure 4. It can be inferred from Figure 4 that the EMF response decreases for $\mathrm{pH}$ above 8 and increases for $\mathrm{pH}$ below 6 .

The EMF response of the biosensor is also affected by the change in solution temperature. During this study, we measured temperature range from $20^{\circ} \mathrm{C}$ to $75^{\circ} \mathrm{C}$. The biosensor has shown maximum response at $40^{\circ} \mathrm{C}$ and above this temperature the EMF response was decreasing as shown in Figure 5. This is because at high temperature, the enzyme molecules might be denatured, whereas at $40^{\circ} \mathrm{C}$ the galactose oxidase has maximum activity. We did all experiments at room temperature due to ease in the handling of the experimental setup and to avoid from the possible evaporation of analyte solution [46].

3.3. Study of Common Interfering Substances on the EMF Response and Response Time of Galactose. Selectivity of a biosensor is a key parameter for the evaluation of performance in the presence of common interferents. In this work, we examined the effect of common interferents such as ascorbic acid, glucose, magnesium ions $\mathrm{Mg}^{2+}$, and uric acid 
TABLE 2: Comparison of the proposed galactose biosensor with the previous work.

\begin{tabular}{lcccccc}
\hline No. & Slope $(\mathrm{mV} /$ decade $)$ & Times respond $(\mathrm{s})$ & Detection limit $(\mathrm{mM})$ & Linear range $(\mathrm{mM})$ & Life times & Reference \\
\hline 1 & - & $\approx 4$ & - & Up to $16 \times 10^{0}$ & 4 weeks & {$[40]$} \\
2 & - & 60 & $6.0 \times 10^{1}$ & $6.0 \times 10^{1}-2.2 \times 10^{2}$ & $\approx 12$ weeks & {$[42]$} \\
3 & - & - & $3.0 \times 10^{1}$ & $3.0 \times 10^{1}-17 \times 10^{1}$ & 12 weeks & {$[46]$} \\
4 & - & $50-40 \mathrm{~s}$ & $1.0 \times 10^{-2}$ & $1.0 \times 10^{-1}-1.0 \times 10^{0}$ & 1 week & {$[47]$} \\
5 & - & 2 & $1.0 \times 10^{-1}$ & $2.0 \times 10^{0}-2.0 \times 10^{1}$ & - & {$[48]$} \\
6 & $89.10 \pm 1.23$ & 10 & $1.0 \times 10^{0}$ & $1.0 \times 10^{1}-2.0 \times 10^{2}$ & $\approx 4$ weeks & This work \\
\hline
\end{tabular}

on the response of the proposed galactose biosensor-based immobilized $\mathrm{ZnO}$ nanorods using the separation solution method. The calculated selective coefficient values are summarised in Table 1. From the published similar biosensor results have been observed that uric acid and ascorbic acid were causing interference [47], but in this study it was noticed that the proposed galactose biosensor has shown no response to uric acid and a negligible response to ascorbic acid. We further studied the response time of the present galactose biosensor using electrical instrument (Keithley 2400) for the measurement of response time. The biosensor had shown a fast response time of less than 10 seconds as shown in Figure 6. We also studied the effect of galactose concentration on the time response of the biosensor and it was observed that the biosensor shown the inverse time response relation with the galactose concentrations.

3.4. Study of Life Time of Biosensor. During the investigation of stability and life time of the present biosensor, we found that the biosensor has a life time more than four weeks. When the galactose biosensor was tested for four successive weeks and it was observed that the detection limit was higher and sensitivity was almost same. This change in the detection limit could be because of the detachment of the enzyme molecules from the GA.

3.5. Comparison of the Proposed Galactose Sensor With Published Galactose Sensors. Table 2 shows comparative study of the results of the present galactose biosensor with other reported galactose biosensors. The proposed galactose sensor based on the functionalised $\mathrm{ZnO}$ nanorods exhibits low limit of detection, fast time response, acceptable storage stability, high sensitivity with good linearity and also no response to common interferents. All these results reveal that the galactose sensor based on $\mathrm{ZnO}$ nanorods as a transducer, has enhanced performance on the activity of the galactose sensor by providing high surface to the enzyme molecules.

\section{Conclusion}

In this paper, we have constructed for the potentiometric galactose biosensor based on the immobilized $\mathrm{ZnO}$ nanorods with galactose oxidase in combination of the crosslinking molecule for the enzyme, using physical surface assimilation method for immobilization. The galactose biosensor had successfully demonstrated high stability, good linearity, better sensitivity, fast response time, and excellent selectivity towards galactose in the presence of common interferents.
These all obtained results of the proposed biosensor indicate that this biosensor can be used for the monitoring of galactose in milk, food, and blood samples as well as for the clinical purpose.

\section{Acknowledgments}

The authors are thankful to International Science Programme (ISP), Uppsala University, Sweden and Royal University of Phnom Penh (RUPP), Cambodia, who supported this paper.

\section{References}

[1] D. M. Bagnall, Y. F. Chen, Z. Zhu et al., "Optically pumped lasing of $\mathrm{ZnO}$ at room temperature," Applied Physics Letters, vol. 70, no. 17, pp. 2230-2232, 1997.

[2] A. Ohtomo, M. Kawasaki, T. Koida et al., "Double heterostructure based on $\mathrm{ZnO}$ and $\mathrm{Mg}_{x} \mathrm{Zn}_{1-x} \mathrm{O}$," Materials Science Forum, vol. 264-268, no. 2, pp. 1463-1466, 1998.

[3] R. D. Vispute, V. Talyansky, S. Choopun et al., "Heteroepitaxy of $\mathrm{ZnO}$ on $\mathrm{GaN}$ and its implications for fabrication of hybrid optoelectronic devices," Applied Physics Letters, vol. 73, no. 3, pp. 348-350, 1998.

[4] K. K. Kim, J. H. Song, H. J. Jung, W. K. Choi, S. J. Park, and J. $\mathrm{H}$. Song, "The grain size effects on the photoluminescence of $\mathrm{ZnO} / \alpha-\mathrm{Al}_{2} \mathrm{O}_{3}$ grown by radio-frequency magnetron sputtering," Journal of Applied Physics, vol. 87, no. 7, pp. 3573-3575, 2000.

[5] X. Duan, Y. Huang, R. Agarwal, and C. M. Lieber, "Singlenanowire elecctrically driven lasers," Nature, vol. 421, no. 6920, pp. 241-245, 2003.

[6] M. Law, D. J. Sirbuly, J. C. Johnson, J. Goldberger, R. J. Saykally, and P. Yang, "Nanoribbon waveguides for subwavelength photonics integration," Science, vol. 305 , no. 5688, pp. 12691273, 2004.

[7] C. J. Barrelet, A. B. Greytak, and C. M. Lieber, "Nanowire photonic circuit elements," Nano Letters, vol. 4, no. 10, pp. 1981-1985, 2004.

[8] A. B. Greytak, C. J. Barrelet, Y. Li, and C. M. Lieber, "Semiconductor nanowire laser and nanowire waveguide electro-optic modulators," Applied Physics Letters, vol. 87, no. 15, Article ID 151103, pp. 1-3, 2005.

[9] M. Willander, L. L. Yang, A. Wadeasa et al., "Zinc oxide nanowires: controlled low temperature growth and some electrochemical and optical nano-devices," Journal of Materials Chemistry, vol. 19, no. 7, pp. 1006-1018, 2009.

[10] H. Zhang, J. Wu, C. Zhai, N. Du, X. Ma, and D. Yang, "From $\mathrm{ZnO}$ nanorods to 3D hollow microhemispheres: solvothermal synthesis, photoluminescence and gas sensor properties," Nanotechnology, vol. 18, no. 45, Article ID 455604, 2007. 
[11] L. Liao, H. B. Lu, J. C. Li, C. Liu, D. J. Fu, and Y. L. Liu, "The sensitivity of gas sensor based on single $\mathrm{ZnO}$ nanowire modulated by helium ion radiation," Applied Physics Letters, vol. 91, no. 17, Article ID 173110, 2007.

[12] A. Wei, X. W. Sun, J. X. Wang et al., "Enzymatic glucose biosensor based on $\mathrm{ZnO}$ nanorod array grown by hydrothermal decomposition," Applied Physics Letters, vol. 89, no. 12, Article ID 123902, 2006.

[13] A. Umar, M. M. Rahman, S. H. Kim, and Y. B. Hahn, "ZnO nanonails: synthesis and their application as glucose biosensor," Journal of Nanoscience and Nanotechnology, vol. 8, no. 6, pp. 3216-3221, 2008.

[14] L. C. Tien, P. W. Sadik, D. P. Norton et al., "Hydrogen sensing at room temperature with Pt-coated $\mathrm{ZnO}$ thin films and nanorods," Applied Physics Letters, vol. 87, no. 22, Article ID 222106, pp. 1-3, 2005.

[15] T. J. Hsueh, S. J. Chang, C. L. Hsu, Y. R. Lin, and I. C. Chen, "Highly sensitive $\mathrm{ZnO}$ nanowire ethanol sensor with $\mathrm{Pd}$ adsorption," Applied Physics Letters, vol. 91, no. 5, Article ID 053111, 2007.

[16] Z. H. Ibupoto, S. M. U. Ali, C. O. Chey, K. Khun, O. Nur, and M. Willander, "Selective zinc ion detection by functionalised $\mathrm{ZnO}$ nanorods with ionophore," Journal of Applied Physics, vol. 110, no. 10, Article ID 04702, 2011.

[17] Z. H. Ibupoto, S. M. U. Ali, K. Khun, C. O. Chey, O. Nur, and $\mathrm{M}$. Willander, "ZnO nanorods based enzymatic biosensor for selective determination of penicillin," Biosensors, vol. 1, pp. 153-163, 2011.

[18] Z. H. Ibupoto, S. M. U. Ali, K. Khun, and M. Willander, "Lascorbic acid biosensor based on immobilized enzyme on $\mathrm{ZnO}$ nanorods," Journal of Biosensors and Bioelectronics, vol. 2, no. 3, Article ID 1000110, 2011.

[19] K. Khun, Z. H. Ibupoto, S. M. U. Ali, C. O. Chey, O. Nur, and M. Willander, "Iron ion sensor based on functionalized $\mathrm{ZnO}$ nanorods," Electroanalysis, vol. 23, pp. 1-8, 2011.

[20] Q. H. Li, T. Gao, Y. G. Wang, and T. H. Wang, "Adsorption and desorption of oxygen probed from $\mathrm{ZnO}$ nanowire films by photocurrent measurements," Applied Physics Letters, vol. 86, no. 12, Article ID 123117, pp. 1-3, 2005.

[21] X. J. Huang and Y. K. Choi, "Chemical sensors based on nanostructured materials," Sensors and Actuators, B, vol. 122, no. 2, pp. 659-671, 2007.

[22] C. C. Li, Z. F. Du, L. M. Li, H. C. Yu, Q. Wan, and T. H. Wang, "Surface-depletion controlled gas sensing of $\mathrm{ZnO}$ nanorods grown at room temperature," Applied Physics Letters, vol. 91, no. 3, Article ID 032101, 2007.

[23] R. Ghosh, M. Dutta, and D. Basak, "Self-seeded growth and ultraviolet photoresponse properties of $\mathrm{ZnO}$ nanowire arrays," Applied Physics Letters, vol. 91, no. 7, Article ID 073108, 2007.

[24] Y. Qiu and S. Yang, "ZnO nanotetrapods: controlled vaporphase synthesis and application for humidity sensing," Advanced Functional Materials, vol. 17, no. 8, pp. 1345-1352, 2007.

[25] J. Y. Park, D. E. Song, and S. S. Kim, "An approach to fabricating chemical sensors based on $\mathrm{ZnO}$ nanorod arrays," Nanotechnology, vol. 19, no. 10, Article ID 105503, 2008.

[26] S. J. Weese, K. Gosnell, P. West, and S. S. Gropper, "Galactose content of baby food meats: considerations for infants with galactosemia," Journal of the American Dietetic Association, vol. 103, no. 3, pp. 373-375, 2003.

[27] S. Segal, A. Blair, and H. Roth, "The metabolism of galactose by patients with congenital galactosemia," The American Journal of Medicine, vol. 38, no. 1, pp. 62-70, 1965.
[28] A. F. Winder, P. Fells, and R. B. Jones, "Galactose intolerance and the risk of cataract," British Journal of Ophthalmology, vol. 66, no. 7, pp. 438-441, 1982.

[29] G. T. Berry, J. V. Hunter, Z. Wang et al., "In vivo evidence of brain galactitol accumulation in an infant with galactosemia and encephalopathy," Journal of Pediatrics, vol. 138, no. 2, pp. 260-262, 2001.

[30] M. Ruiz, S. Jover, M. Armas et al., "Galactosaemia presenting as congenital pseudoafibrinogenaemia," Journal of Inherited Metabolic Disease, vol. 22, no. 8, pp. 943-944, 1999.

[31] N. V. Guerrero, R. H. Singh, A. Manatunga, G. T. Berry, R. D. Steiner, and L. J. Elsas II, "Risk factors for premature ovarian failure in females with galactosemia," Journal of Pediatrics, vol. 137, no. 6, pp. 833-841, 2000.

[32] K. G. Petry and J. K. V. Reichardt, "The fundamental importance of human galactose metabolism: lessons from genetics and biochemistry," Trends in Genetics, vol. 14, no. 3, pp. 98102, 1998.

[33] S. A. Hansen, "Thin-layer chromatographic method for the identification of mono-, di- and trisaccharides," Journal of Chromatography A, vol. 107, no. 1, pp. 224-226, 1975.

[34] S. L. Wehrli, R. Reynolds, J. Chen, C. Yager, and S. Segal, "Metabolism of ${ }^{13} \mathrm{C}$ galactose by lymphoblasts from patients with galactosemia determined by NMR spectroscopy," Molecular Genetics and Metabolism, vol. 77, no. 4, pp. 296-303, 2002.

[35] V. Rajendran and J. Irudayaraj, "Detection of glucose, galactose, and lactose in milk with a microdialysis-coupled flow injection amperometric sensor," Journal of Dairy Science, vol. 85, no. 6, pp. 1357-1361, 2002.

[36] D. Schumacher, J. Vogel, and U. Lerche, "Construction and applications of an enzyme electrode for determination of galactose and galactose-containing saccharides," Biosensors and Bioelectronics, vol. 9, no. 2, pp. 85-89, 1994.

[37] N. Watanabe and S. Kawasaki, "Determination of galactose in human plasma by HPLC with electrochemical detection," Biomedical Chromatography, vol. 2, no. 3, pp. 95-98, 1987.

[38] E. E. Szabó, N. Adányi, and M. Váradi, "Application of biosensor for monitoring galactose content," Biosensors and Bioelectronics, vol. 11, no. 10, pp. 1051-1058, 1996.

[39] E. Ekinci and A. Paşahan, "Poly (4-methoxyphenol) film as a galactose-sensing material," European Polymer Journal, vol. 40, no. 8, pp. 1605-1608, 2004.

[40] S. K. Sharma, S. K. Singh, N. Sehgal, and A. Kumar, "Biostrip technique for detection of galactose in dairy foods," Food Chemistry, vol. 88, no. 2, pp. 299-303, 2004.

[41] S. K. Sharma, R. Singhal, B. D. Malhotra, N. Sehgal, and A. Kumar, "Langmuir-Blodgett film based biosensor for estimation of galactose in milk," Electrochimica Acta, vol. 49, no. 15, pp. 2479-2485, 2004.

[42] S. K. Sharma, R. Singhal, B. D. Malhotra, N. Sehgal, and A. Kumar, "Biosensor based on Langmuir-Blodgett films of poly(3-hexyl thiophene) for detection of galactose in human blood," Biotechnology Letters, vol. 26, no. 8, pp. 645-647, 2004.

[43] J. Wang, S. He, S. Zhang et al., "Controllable synthesis of zno nanostructures by a simple solution route," Materials SciencePoland, vol. 27, no. 2, pp. 477-484, 2009.

[44] R. H. Garret and C. M. Grisham, Biochemistry, Saunders College Publishing, Orlando, Fla, USA, 1995.

[45] J. A. Cooper, W. Smith, M. Bacila, and H. Medina, "Galactose oxidase from Polyporus circinatus," The Journal of Biological Chemistry, vol. 234, no. 3, pp. 445-448, 1959.

[46] S. K. Sharma, Suman, C. S. Pundir, N. Sehgal, and A. Kumar, "Galactose sensor based on galactose oxidase immobilized in 
polyvinyl formal," Sensors and Actuators, B, vol. 119, no. 1, pp. 15-19, 2006.

[47] K. N. Lee, Y. Lee, and Y. Son, "Enhanced sensitivity of a galactose biosensor fabricated with a bundle of conducting Polymer microtubules," Electroanalysis, vol. 23, no. 9, pp. 2125-2130, 2011.

[48] E. Evik, M. Şenel, and M. Fatih Abasyank, "Construction of biosensor for determination of galactose with galactose oxidase immobilized on polymeric mediator contains ferrocene," Current Applied Physics, vol. 10, no. 5, pp. 1313-1316, 2010. 

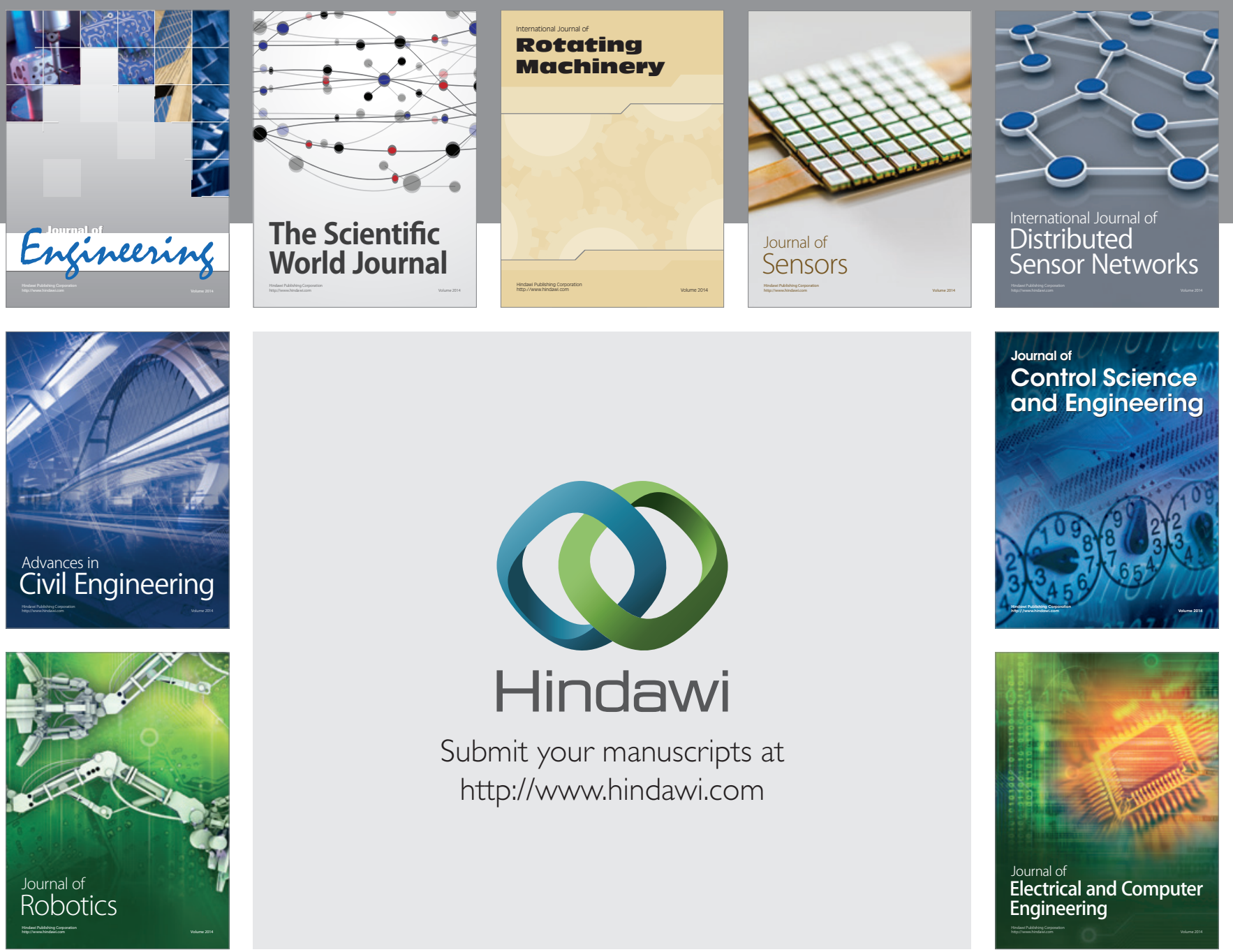

Submit your manuscripts at

http://www.hindawi.com
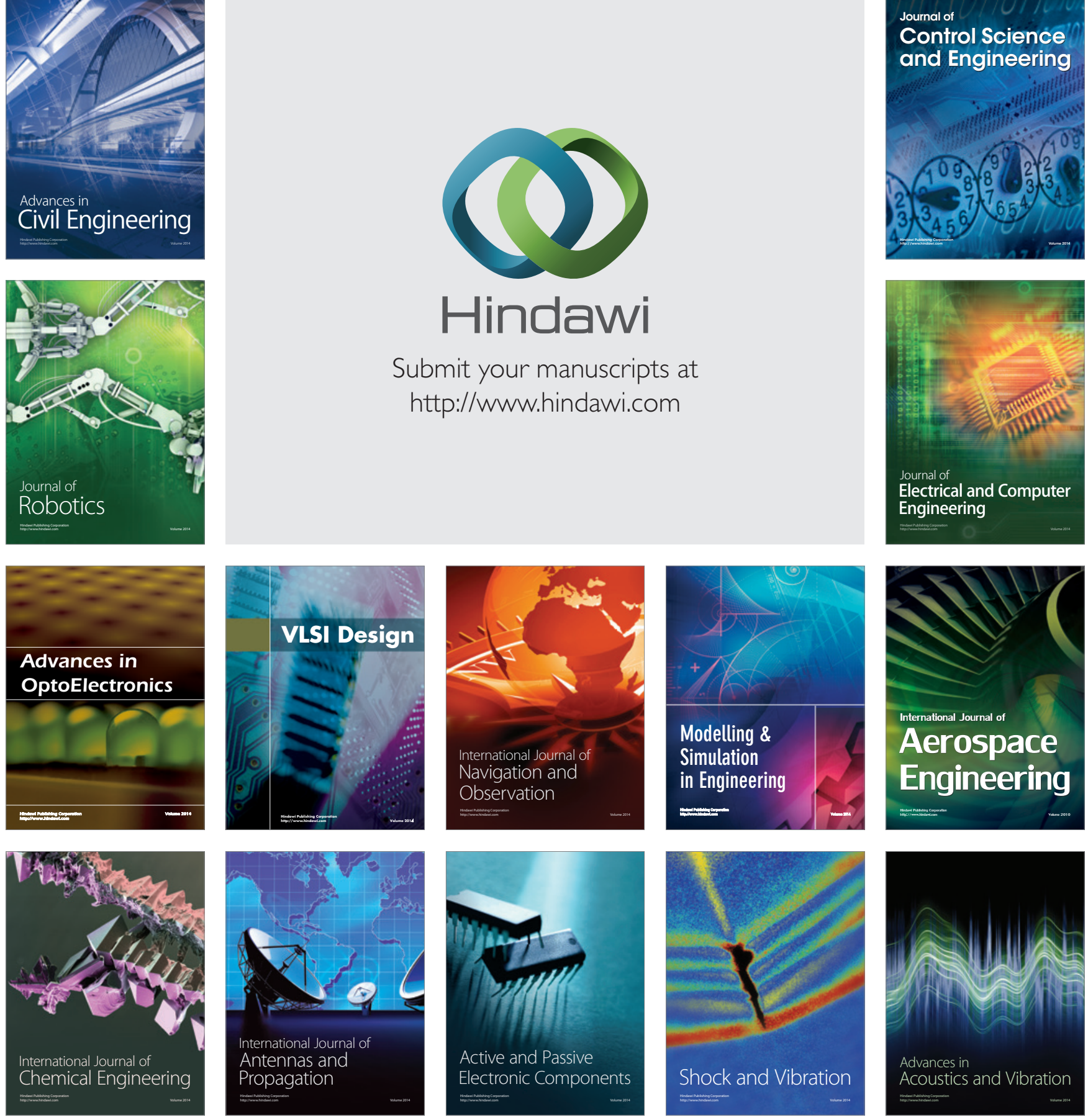